\title{
Sigmoidal normal faults and evidence for vertical-axis block rotation in an oblique convergent margin: A 3D-seismic example offshore Colombia
}

\begin{tabular}{|c|c|}
\hline Journal: & The Leading Edge \\
\hline Manuscript ID & Draft \\
\hline Manuscript Type: & December 2021: Latin America \\
\hline $\begin{array}{l}\text { Date Submitted by the } \\
\text { Author: }\end{array}$ & $n / a$ \\
\hline Complete List of Authors: & $\begin{array}{l}\text { Galindo, Pedro; Ecopetrol; Imperial College London, Department of Earth } \\
\text { Science and Engineering } \\
\text { Lonergan, Lidia; Imperial College London, Department of Earth Science } \\
\text { and Engineering }\end{array}$ \\
\hline Keywords: & seismic, strike-slip, faults, 3D, interpretation \\
\hline Subject Areas: & $\begin{array}{l}\text { Interpretation Methods and Interdisciplinary Studies, Seismic Amplitude } \\
\text { Interpretation }\end{array}$ \\
\hline
\end{tabular}
SCHOLARONE $^{\mathrm{m}}$
Manuscripts $^{\text {Manusion }}$ 


\title{
Sigmoidal normal faults and evidence for vertical-axis block
}

\section{rotation in an oblique convergent margin: A 3D-seismic}

\section{example offshore Colombia}

\author{
Pedro A. Galindo ${ }^{1 *}$ and Lidia Lonergan ${ }^{1}$ \\ ${ }^{1}$ Department of Earth Science and Engineering, Imperial College London \\ Corresponding author; Pedro Galindo (pedro.galindo@ecopetrol.com.co) \\ * Current address: Ecopetrol S.A., Bogotá, Colombia
}

\begin{abstract}
Sigmoidal fold and fault geometries are typical kinematic indicators of strike-slip fault zones. We document km-scale, normal faults with sigmoidal plan-view geometries within the dextral pull-apart Bahia Basin, at the rear of the obliquely convergent South Caribbean Deformed Belt, offshore Colombia. Using three-dimensional seismic reflection data calibrated to wells, closely spaced, low-displacement, planar normal faults are mapped within the Miocene strata. A series of seismic horizontal (time) slices and computed seismic attributes are used to interpret the $3 \mathrm{D}$ configuration of these faults. The closely spaced faults display an E-W trend, with a progressive rotation into a NW-SE trend. In map view, the fault traces curve towards their tips describing a sigmoidal-Z geometry that terminate at discrete NE-SW trending fault zones. The structures observed may correspond to either tension fractures (T) which form theoretically at $45^{\circ}$, or antithetic shear fractures ( $\left.\mathrm{R}^{\prime}\right)$ with normal displacement formed at $50^{\circ}-70^{\circ}$ to the boundaries of a dextral shear zone. These scenarios lead to a clockwise block rotation of between $20^{\circ}$ and $40^{\circ}$ within the shear zone. This study shows the first example of vertical-axis block
\end{abstract}


rotations observed offshore in the western end of the South Caribbean margin and is an important example of the use of 3D seismic data to identify rotations where paleomagnetic studies are not available.

\section{INTRODUCTION}

En-echelon and sigmoidal structures are typical kinematic indicators of strike-slip tectonics and occur at $\mathrm{cm}$ - to the $\mathrm{km}$-scale. A classic example are sigmoidal veins that form as rotated tensile fractures during simple shear (e.g. Ramsay and Huber, 1983; Bons et al., 2012); but sigmoidal and en-echelon normal faults, folds and thrusts are also common features of strike-slip basins (e.g. Richard et al., 1995; Waldron, 2005; Mann, 2007; Dooley and Schreurs, 2012; Allen and Allen, 2013). In simple shear deformation, the maximum compressive stress $(\sigma 1)$ acts at $45^{\circ}$ to the boundaries of the shear zone (Fig. 1). In response, tension fractures (T) and normal faults form parallel to the maximum principal compression and perpendicular to the minimum stress. As a result of the continuous deformation (Fig. 1B-D), and because the orientation of the instantaneous stretching axis remains fixed with respect to the boundaries of the shear zone, new faults continuously form at $45^{\circ}$, and the early formed faults rotate and amalgamate with the new ones creating a sigmoidal shape (Fig. 1E) (e.g. Ramsay and Huber, 1983). This passive rotation of the older segments of the fault implies that the blocks bounded by these faults have also been rotated in response to the overall shear sense (e.g. Freund, 1974; Peacock et al., 1998; Waldron, 2005). Analogue experiments investigating strike-slip faulting, have identified the development of sigmoidal faults as a kinematic indicator of block rotation, where the sigmoidal curvature define the sense of rotation. Hence, sigmoidal $\mathrm{Z}$ shapes of normal faults and veins are indicative of clockwise rotation, while sigmoidal S shapes indicate counterclockwise rotation (Freund, 
1974; Gapais et al., 1991; Schreurs, 2003). At larger scales, vertical-axis block rotation has been documented in strike-slip basins around the globe and can be detected by paleomagnetic (e.g. Ron et al., 1984; Luyendyk et al., 1985; Lewis and Stock, 1998; Chen et al., 2002), geodetic (e.g. Allmendinger et al., 2007; McCaffrey et al., 2007; Wallace et al., 2009) and seismologic (e.g. Nicholson et al., 1986a, 1986b; McCaffrey, 2005; Wallace et al., 2007) methods.

At oblique convergent plate boundaries both observational and theoretical studies have shown that because of strain partitioning the active strike-slip faults, which take up a significant proportion of the strike-parallel motion, occur some distance away from the active subduction zone towards the rear of the system (e.g. Fitch, 1972; Beck, 1983; McCaffrey, 1992; Beck et al., 1993; Yu et al., 1993; Teyssier et al., 1995). Mechanical analyses such as that of Platt (2000), show that localized deformation is expected at the rear of the wedge along a discrete zone of strike-slip deformation where vertical-axis block rotation, amongst other structures, might be expected to occur. To date, examples of block rotation in strike-slip zones at the rear of marine accretionary-prisms have yet to be documented. Here we use high-quality, post-stack, time migrated 3D seismic reflection data to describe a unique example of offshore sigmoidal-normal faults that imply vertical-axis block rotation in a zone of strike-slip deformation at the rear of the present-day accretionary prism, offshore northern Colombia.

\section{Tectonic setting}

The southern margin of the Caribbean has been widely recognized as region of oblique subduction and strain partitioning (e.g. Avé Lallemant, 1997; Escalona and Mann, 2011) with strike-slip deformation at the rear of the accretionary wedge occurring along offshore Venezuela (e.g. Beardsley and Avé Lallemant, 2007; Gorney et al., 2007; Audemard and Castilla, 2016) and 
Colombia (Gomez, 2001; Galindo, 2016; Galindo and Lonergan, 2020; Vence and Mann, 2020).

The study area lies at the western end of the Oca fault within the dextral Bahia Basin located in the NW corner of South America, offshore Colombia out-board of major, regional strike-slip faults, which define the geometry of the NW corner of South America (Fig. 2A). The evolution of Bahia Basin has been described recently by Galindo and Lonergan (2020). It initially formed as a dextral transtensional basin from late Oligocene to Late Miocene times, most likely as the offshore extension of the E-W trending Oca fault (Fig. 2A) and was subsequently inverted during Plio-Pliocene times due to transpression and the northward movement of the Santa Marta massif. Furthermore, pervasive mud volcanism is also present in the area, whose source is interpreted as overpressured shales of Oligocene age (Galindo and Lonergan, 2020).

The Bahia Basin is located ca. $60 \mathrm{~km}$ behind the toe of the South Caribbean Deformed Belt. This is an area of complex deformation between the offshore-compressional folding and the onshore large strike-slip systems that dominate the NW corner of South America. The South Caribbean Deformed Belt is the accretionary prism formed along the convergent margin between the Caribbean and South American Plates, offshore Colombia and Venezuela (Ladd and Truchan, 1983; Ladd et al., 1984). The accretionary prism is growing in response to the ESE-directed subduction of the Caribbean Plate at a rate of ca. $20 \mathrm{~mm} / \mathrm{yr}$ (e.g. Trenkamp et al., 2002; Symithe et al., 2015; Mora-Páez et al., 2019). The sediments within the prism are interpreted as the offscrapping of sediments from the subducted crust, and the sediments deposited on top of the prism by prograding-deltaic systems coming from the continent (e.g. Magdalena River; Fig. 2A). However, the anomalous high thickness of the Caribbean crust and the low angle of subduction, prevent the formation of a typical bathymetric trench in front of the wedge as occurred in other areas of oceanic plateau subduction (Mann and Taira, 2004; Kroehler et al., 2011). The age of 
the South Caribbean Deformed Belt is still a matter of debate and may respond to regional and local deformation processes. Regionally, Müller et al. (1999), propose a NW-SE convergence between North and South America since early Eocene times resulting in 200-400 km of shortening. Locally, east-west plate convergence is attributed to the collision of the Panama Arc since middle to late Miocene times (Duque-Caro, 1979; Montes et al., 2012a, 2012b, 2015). The relative eastern movement of the Caribbean Plate forms dextral strike-slip systems along the northern margin of the South American Plate (e.g. Audemard and Castilla, 2016), where the W-E Oca-Ancon-El Pilar Fault System constitutes the main fault system along Colombia and Venezuela (Audemard, 1996) (Fig. 2A). The western segment of this dextral fault system (i.e. the Oca Fault), forms the sharp-northern boundary of the Santa Marta Massif, crosses the Guajira Peninsula, and continues into the northern area of the Maracaibo Gulf. The western end of the Oca Fault System is interpreted at different splays within the NW corner of the Santa Marta Massif (Audemard, 1996) and an offshore splay that causes the development of the Aguja Canyon (Restrepo-Correa and Ojeda, 2010). The Bahia Basin is located offshore in front of the NW corner of the Santa Marta Massif, which is also the termination of the NW-SE trending, leftlateral Santa Marta-Bucaramanga Fault (Fig. 2A).

\section{Data and methods}

A high-quality, pre-stack, time migrated (PSTM) seismic volume covering an approximate area of $1500 \mathrm{~km}^{2}$, was used for this study. It consists of 1196 lines (NE-SW) at a spacing of $25 \mathrm{~m}$, and 4056 traces (NW-SE) at a spacing of $12.5 \mathrm{~m}$. In depth, the volume has a record length of 7 seconds TWT (ca. $8 \mathrm{~km}$ ), with a sample rate of $4 \mathrm{~ms}$. The seismic volume has an average frequency content of $30 \mathrm{~Hz}$ which gives a resolution of ca. $20 \mathrm{~m}$ in the vertical and ca. $25 \mathrm{~m}$ of 
horizontal resolution. Biostratigraphic data from one well within the seismic volume has allowed us to assign late Oligocene to Recent ages to the stratigraphy (Fig. 2B). Time slices and seismic profiles sections are used in order to fully characterize the complex tridimensional configuration of the deformation. Furthermore, volume-based seismic attributes such us coherency (e.g. Marfurt et al., 1998) and spectral decomposition (e.g. Partyka et al., 1999) are also included to facilitate the interpretation of fault planes.

\section{RESULTS}

\section{Seismic expression and structure of the Bahia Basin}

Several unconformities can be interpreted in the seismic data, including regional unconformities that divide the basin into a series of tectono-stratigraphic units. The most important unconformity that can be mapped continuously through the area of the survey is the upper Miocene to lower Pliocene unconformity. The time-structure map (Fig. 3A) shows a complex structural configuration with the presence of several highs and lows and a range in time between $1400 \mathrm{~ms}$ and $5000 \mathrm{~ms}$ (TWT). This surface shows a broadly triangular basin bounded by faults A, C and D (Fig. 3B). Fault A, like the trend of the structures within the thrust belt, strikes NE-SW, almost parallel with the limits of the 3D seismic volume, and continuing the trend of the coastline and shelf break present towards the SW (Fig. 2A). This fault is identified by the alignment of several mud volcanoes that erupt on the seabed and the thickening towards the south of Plio-Pleistocene sediments within the Bahia Basin (Fig. 2A-B). The E-W trending Fault C corresponds to the southern boundary of the basin and displays a similar trend to the Oca Fault System further to the east. Towards the east, the N-S trending Fault D is interpreted as a reverse fault related to the northern termination of the Santa Marta-Bucaramanga Fault (Galindo and Lonergan, 2020). 
Within the basin, the Bahia Fault is the most important structure. The NE-SW cross-basinal fault is composed of three left-stepping segments (Bs, Bc, Bn; Fig. 3), which are the south-eastern boundary of structural highs located in the footwall side of the fault (southern-SH, central-CH and northern highs-NH in Fig. 3B). On the south-eastern side of the Bahia Fault a main depocenter area is formed, within which ca. 4 s TWT (ca. $4.6 \mathrm{~km})$ of Neogene sediments were deposited.

\section{Structures below the upper Miocene to lower Pliocene unconformity}

The main observation that defines the interpretation of the upper Miocene to lower Pliocene unconformity is the strong difference in the seismic character below and above the unconformity. Below the unconformity the imaging is less clear and a high density of low displacement normal faults disrupts the seismic response, whereas above the reflections are clearer, continuous and rarely affected by faulting (Fig. 4). Beneath the upper Miocene to lower Pliocene unconformity the footwall of the Bahia Fault is deformed by a large number of closely spaced, lowdisplacement, extensional faults. The faults have a planar geometry, dip between $45^{\circ}$ and $60^{\circ}$, and affect just the Miocene section deforming $~ 1000 \mathrm{~m}$ ? of stratigraphy (Fig. 4). A series of seismic time slices and seismic attributes are used to interpret the $3 \mathrm{D}$ configuration of these faults (Fig. 5). The images show a series of closely spaced E-W trending faults, with a progressive rotation towards the north to a NW-SE trend. In map view, the fault traces curve towards their tips describing a sigmoidal-Z geometry. The curvature of the faults is particularly well imaged in the spectral decomposition images (e.g. Fig. 5C). The sigmoidal faults terminate at discrete NE-SW trending fault zones (i.e. Faults Z, Z' and Z'' in Fig. 5D), which are subparallel to the regional Fault A and the Bahia Fault. 


\section{DISCUSSION}

\section{Interpretation of sigmoidal-Z geometries}

The geometry and location of the sigmoidal-Z normal faults are kinematic indicators of a dextral strike-slip shear zone occurring between the Fault A and the Bahia Fault and suggest a clockwise rotation of the northern block within the Bahia Basin. In map view, normal faults are expected to occur in simple-shear zones at $45^{\circ}$ from the margin, although this value may decrease or increase in areas of either transtension or transpression, respectively (Fig. 1A) (Sanderson and Marchini, 1984). Experiments of analogue modelling that use layered dry-quartz sand and glass powder over a viscous-detachment level has been performed to analyze the distributed strain within a dextral strike-slip shear zone (Schreurs, 1994, 2003). Similarly, the blocks within the Bahia Basin may present the Oligocene shale section as a viscous detachment. However, in these experiments sigmoidal faults are formed at high angle against the master faults (as antithetic Riedel shears, R'; Fig. 1A) and correspond to the boundaries of rotated blocks. These experiments show the development of dextral faults subparallel to the boundaries of the shear zone, and sinistral strike-slip faults at high angles (ca. $\left.50^{\circ}-70^{\circ}\right)$ to the master-dextral strike-slip faults. With increasing strain, the sinistral faults rotate and propagate laterally, acquiring a sigmoidal-Z shape in map view. The rotations about vertical axes of the antithetic faults and the blocks in between create space problems that respond as small dip-slip components that change along strike. Hence, these faults show a small normal displacement at the end, no dip-slip displacement at the center, and a small inverse displacement at the opposite end of the sigmoidal fault, describing them as scissor faults (Schreurs, 2003). In the northern block of the footwall of the Bahia Fault, Fig. 3 shows the presence of fault zones subparallel to the boundaries of the 
shear zone (i.e. Faults Z, Z', Z''), together with sigmoidal-Z faults at a high angle to the Bahia Fault. These sigmoidal faults also illustrate a small left-lateral displacement (see blue horizon on Fig. 5E) similar to the results of the analogue modelling, supporting that these formed as antithetic faults (R' shears). However, the faults display a continuous normal displacement along the strike of the faults, different to that predicted by analogue models.

In summary, the presence of sigmoidal $\mathrm{Z}$ geometries in map view is a typical kinematic indicator of vertical-axes clockwise rotation in a dextral strike-slip shear zone. However, in comparison to the theoretical structures formed within a shear zone, the structures observed in the northern block of the footwall of the Bahia Fault may correspond to normal faults that form parallel to tension fractures (T) formed at $45^{\circ}$ to the Bahia Fault, or antithetic shear fractures (R') formed at $50^{\circ}-70^{\circ}$ to the boundaries of the shear zone. These possible scenarios lead to different amounts of block rotation within the shear zone. If the faults initially formed as normal faults, the current presence of NW-SE faults proposes a maximum $45^{\circ}$ clockwise rotation, while antithetic shear fractures would support a clockwise rotation between $20^{\circ}$ and $40^{\circ}$.

\section{Implications for the tectonics of NW South America}

This deformation was occurring in the context of oblique subduction along the South Caribbean Deformed Belt since Miocene times. A regional section (Fig. 2B) shows that whilst thrusts dominate the frontal parts of the accretionary prism, the deformation style significantly changed at the rear of the wedge in the area of the Bahia Fault and basin. Our results show that the deformation at the rear of the wedge is dominated by complex strike-slip tectonics and provides evidence of partitioning of deformation associated with the oblique subduction of the Caribbean Plate (Fig. 6). Strain partitioning between strike-normal motion at the frontal part of the 
forearc/accretionary prism near the subduction zone and strike-parallel motion towards the rear of the accretionary wedge has been observed in many subduction zones worldwide (e.g. Fitch, 1972; McCaffrey, 1992; Yu et al., 1993) and is predicted from both theoretical and analogue models (e.g. Platt, 2000; McClay et al., 2004). Furthermore, given the relative sense of movement of the subducted plate (i.e. Caribbean) and its angle of obliquity with respect to the trend of the accretionary front $\left(\mathrm{ca} .50^{\circ}\right)$, mechanical models of accretionary viscous wedges predict the possible development of different styles of strike-slip deformation, including rotations about vertical axes (Fig 10 in Platt, 2000), as observed within the northern block in the footwall of the Bahia Fault (Fig. 6).

In the Miocene the angle of obliquity between the direction of subduction and strike of the frontal toe of the accretionary prism may have been different from that observed today. However a variety of studies including the use of tomography (van der Hilst and Mann, 1994; Miller et al., 2009; Bezada et al., 2010a, 2010b; van Benthem et al., 2013), GPS measurements (Weber et al., 2001; Trenkamp et al., 2002; Symithe et al., 2015), seismology (Corredor, 2003; Cortés et al., 2005), field studies (e.g. Bayona et al., 2010; Cardona and Ojeda, 2010; Lara et al., 2013; Cardona et al., 2014) and tectonic plate restorations (e.g. Müller et al., 1999; Pindell and Kennan, 2009; Bochman et al., 2014; Montes et al., 2019) have supported the model of an eastern movement of the Caribbean Plate relative to South America since the Miocene, which implies an angle of obliquity at least equal to that observed today. Moreover, the obliquity is expected to be higher in the location of the Bahia Basin where the South Caribbean Deformed Belt curves to the east in comparison to regions south of the Magdalena Fan where the accretionary prism forms a higher angle with the Caribbean Plate (i.e. Sinu Fold Belt; e.g. Flinch, 2003). Clockwise verticalaxes block rotations have also been documented onshore in Venezuela and Colombia from 
several paleomagnetic studies (summarized by Audemard, 2009; and Montes et al., 2010, respectively) as a result of the complex interaction of multiple tectonic blocks during the evolution of the NW corner of South America. Hence, the example of rotations that we document in the footwall of the Bahia Basin is the first example of rotations observed offshore in the region. Moreover, this is an important example of how 3D seismic data may help to identify vertical-axes rotations where paleomagnetic studies are not possible.

\section{ACKNOWLEDGMENTS}

This study is part of the $\mathrm{PhD}$ project completed by P. Galindo at Imperial College. We thank the 'Departamento Administrativo de Ciencia, Tecnología e Innovación' (COLCIENCIAS) and their "Francisco José de Caldas" Scholarship Programme, providers of the funding for this research. Thanks to ECOPETROL S. A. for providing the data used for this research, and for the permission to publish these results. Halliburton Software and Services, is acknowledged for providing the Landmark software used to interpret the seismic data under a university software grant to Imperial College.

\section{REFERENCES CITED}

Allen, P. A., and J. R. Allen, 2013, Basin Analysis: Principles and Applications to Petroleum Play Assessment., Third edit.: Wiley-Blackwell.

Allmendinger, R. W., R. Reilinger, and J. Loveless, 2007, Strain and rotation rate from GPS in Tibet, Anatolia, and the Altiplano: Tectonics, 26.

Audemard, F. A., 1996, Paleoseismicity studies on the Oca-Ancón fault system, northwestern Venezuela: Tectonophysics, 259, 67-80.

Audemard, F. A., 2009, Key issues on the post-Mesozoic Southern Caribbean Plate boundary: Geological Society, London, Special Publications, 328, 569-586.

Audemard, F. A., and R. Castilla, 2016, Present-day stress tensors along the southern Caribbean plate boundary zone from inversion of focal mechanism solutions: A successful trial: Journal of South American Earth Sciences, 71, 309-319. 
Bayona, G., G. Jiménez, C. Silva, A. Cardona, C. Montes, J. Roncancio, and U. Cordani, 2010, Paleomagnetic data and K-Ar ages from Mesozoic units of the Santa Marta massif: A preliminary interpretation for block rotation and translations: Journal of South American Earth Sciences, 29, 817-831.

Beardsley, A. G., and H. G. Avé Lallemant, 2007, Oblique collision and accretion of the Netherlands Leeward Antilles to South America: Tectonics, 26, 1-16.

Beck, Jr. M. E., 1983, On the mechanics of tectonic transport in zones of oblique subduction: Tectonophysics, 93, 1-11.

Beck, Jr. M. E., C. Rojas, and J. Cembrano, 1993, On the nature of buttressing in margin-parallel strike-slip fault systems: Geology, 21, 755.

van Benthem, S., R. Govers, W. Spakman, and R. Wortel, 2013, Tectonic evolution and mantle structure of the Caribbean: Journal of Geophysical Research: Solid Earth, 118, 3019-3036.

Bezada, M. J., A. Levander, and B. Schmandt, 2010a, Subduction in the southern Caribbean: Images from finite-frequency P wave tomography: Journal of Geophysical Research: Solid Earth, 115, 1-19.

Bezada, M. J., M. B. Magnani, C. a. Zelt, M. Schmitz, and A. Levander, 2010b, The CaribbeanSouth American plate boundary at 65W: Results from wide-angle seismic data: Journal of Geophysical Research: Solid Earth, 115.

Bochman, L., D. van Hinsbergen, T. H. Torsvik, W. Spakman, J. L. Pindell, L. M. Boschman, D. J. J. van Hinsbergen, T. H. Torsvik, W. Spakman, and J. L. Pindell, 2014, Kinematic reconstruction of the Caribbean region since the Early Jurassic: Earth Science Reviews, 16, 6829.

Bons, P. D., M. A. Elburg, and E. Gomez-Rivas, 2012, A review of the formation of tectonic veins and their microstructures: Journal of Structural Geology, 43, 33-62.

Cardona, A., and G. Y. Ojeda, 2010, Special volume: Geological evolution of the Sierra Nevada de Santa Marta and adjacent basins, Colombian Caribbean region: Journal of South American Earth Sciences, 29, 761-763.

Cardona, A., M. Weber, V. Valencia, C. Bustamante, C. Montes, U. Cordani, and C. M. Muñoz, 2014, Geochronology and geochemistry of the Parashi granitoid, NE Colombia: Tectonic implication of short-lived Early Eocene plutonism along the SE Caribbean margin: Journal of South American Earth Sciences, 50, 75-92.

Chen, Y., S. Gilder, N. Halim, J. P. Cogné, and V. Courtillot, 2002, New paleomagnetic constraints on central Asian kinematics: Displacement along the Altyn Tagh fault and rotation of the Qaidam Basin: Tectonics, 21, 6-1-6-19.

Corredor, F., 2003, Seismic strain rates and distributed continental deformation in the northern Andes and three-dimensional seismotectonics of northwestern South America: Tectonophysics, 372, 147-166.

Cortés, M., J. Angelier, and B. Colletta, 2005, Paleostress evolution of the northern Andes (Eastern Cordillera of Colombia): Implications on plate kinematics of the South Caribbean region: Tectonics, $\mathbf{2 4}$, n/a-n/a.

Dooley, T. P., and G. Schreurs, 2012, Analogue modelling of intraplate strike-slip tectonics: A review and new experimental results: Tectonophysics, 574-575, 1-71.

Duque-Caro, H., 1979, Major structural elements and evolution of northwestern Colombia, in J. S. Watkins, L. Montadert, and P. Wood, eds., AAPG Memoir 29: Geological and Geophysical Investigations of Continental Margins, American Association of Petroleum Geologists, 329-351. 
Fitch, T. J., 1972, Plate convergence, transcurrent faults, and internal deformation adjacent to Southeast Asia and the western Pacific: Journal of Geophysical Research, 77, 4432-4460.

Flinch, J. F., 2003, Structural evolution of the Sinu-Lower Magdalena area (Northern Colombia), in C. Bartolini, R. T. Buffler, and J. Blickwede, eds., AAPG Memoir 79: The Circum-Gulf of Mexico and the Caribbean: Hydrocarbon habitats, basin formation, and plate tectonics, American Association of Petroleum Geologists, 776-796.

Freund, R., 1974, Kinematics of transform and transcurrent faults: Tectonophysics, 21, 93-134.

Galindo, P., 2016, Transtension and transpression in an oblique subduction setting: Evolution of the Bahia Basin, Colombian Caribbean margin.270p.

Galindo, P., and L. Lonergan, 2013, Evolution of the Bahia Basin : Evidence for Vertical-Axis Block Rotation and Basin Inversion at the Caribbean Plate Margin Offshore Northern Colombia: AAPG International Conference and Exhibition, 11.

Galindo, P. A., and L. Lonergan, 2020, Basin Evolution and Shale Tectonics on an Obliquely Convergent Margin: The Bahia Basin, Offshore Colombian Caribbean: Tectonics, 39, 32.

Gapais, D., G. Fiquet, and P. R. Cobbold, 1991, Slip system domains, 3. New insights in fault kinematics from plane-strain sandbox experiments: Tectonophysics, 188, 143-157.

Gomez, I., 2001, Structural style and evolution of the Cuisa fault system, Guajira, Colombia.153p.

Gorney, D., A. Escalona, P. Mann, M. B. Magnani, A. Levander, G. Christeson, C. a. Zelt, M. Schmitz, S. Clark, M. C. Guedez, M. J. Bezada, Y. Arogunmati, T. Aitken, and A. Beardsley, 2007, Chronology of Cenozoic tectonic events in western Venezuela and the Leeward Antilles based on integration of offshore seismic reflection data and on-land geology: AAPG Bulletin, 91, 653-684.

van der Hilst, R. P., and P. Mann, 1994, Tectonic implications of tomographic images of subducted lithosphere beneath northwestern South America: Geology, 22, 451.

Kroehler, M. E., P. Mann, A. Escalona, and Gail. L. Christeson, 2011, Late Cretaceous-Miocene diachronous onset of back thrusting along the South Caribbean deformed belt and its importance for understanding processes of arc collision and crustal growth: Tectonics, 30, 31.

Ladd, J. W., and M. Truchan, 1983, Compressional Features Across the Caribbean Margin of Colombia, in A. W. Bally, ed., AAPG Studies in Geology 15: Seismic Expression of Structural Styles., .

Ladd, J. W., M. Truchan, M. Talwani, P. L. Stoffa, P. Buhl, R. Houtz, A. Maufiret, and G. K. Westbrook, 1984, Seismic reflection profiles across the southern margin of the Caribbean, in W. E. Bonini, R. B. Hargraves, and R. Shagam, eds., The Caribbean-South American Plate Boundary and Regional Tectonics, Vol. 162. Geological Society of America Memoirs $162,153-159$.

Lara, M., A. Cardona, G. Monsalve, J. Yarce, C. Montes, V. Valencia, M. Weber, F. de La Parra, D. Espitia, and M. López-Martínez, 2013, Middle Miocene near trench volcanism in northern Colombia: A record of slab tearing due to the simultaneous subduction of the Caribbean Plate under South and Central America? Journal of South American Earth Sciences, 45, 24-41.

Lewis, C. J., and J. M. Stock, 1998, Paleomagnetic evidence of localized vertical axis rotation during Neogene extension, Sierra San Fermín, northeastern Baja California, Mexico: Journal of Geophysical Research: Solid Earth, 103, 2455-2470. 
Luyendyk, B. P., M. J. Kamerling, R. R. Terres, and J. S. Hornafius, 1985, Simple shear of southern California during Neogene time suggested by paleomagnetic declinations (USA).: Journal of Geophysical Research, 90.

Mann, P., 2007, Global catalogue, classification and tectonic origins of restraining- and releasing bends on active and ancient strike-slip fault systems: Geological Society, London, Special Publications, 290, 13-142.

Mann, P., and A. Taira, 2004, Global tectonic significance of the Solomon Islands and Ontong Java Plateau convergent zone: Tectonophysics, 389, 137-190.

Marfurt, K. J., R. L. Kirlin, S. L. Farmer, and M. S. Bahorich, 1998, 3-D seismic attributes using a semblance-based coherency algorithm: Geophysics, 63, 1150-1165.

McCaffrey, R., 1992, Oblique plate convergence, slip vectors, and forearc deformation: Journal of Geophysical Research, 97, 8905-8915.

McCaffrey, R., 2005, Block kinematics of the Pacific-North America plate boundary in the southwestern United States from inversion of GPS, seismological, and geologic data: Journal of Geophysical Research: Solid Earth, 110, 1-27.

McCaffrey, R., A. I. Qamar, R. W. King, R. Wells, G. Khazaradze, C. a. Williams, C. W. Stevens, J. J. Vollick, and P. C. Zwick, 2007, Fault locking, block rotation and crustal deformation in the Pacific Northwest: Geophysical Journal International, 169, 1315-1340.

McClay, K. R., P. S. Whitehouse, T. Dooley, and M. Richards, 2004, 3D evolution of fold and thrust belts formed by oblique convergence: Marine and Petroleum Geology, 21, 857-877.

Miller, M. S., A. Levander, F. Niu, and A. Li, 2009, Upper mantle structure beneath the Caribbean-South American plate boundary from surface wave tomography: Journal of Geophysical Research, 114, B01312.

Montes, C., G. Guzmán, G. Bayona, A. Cardona, V. Valencia, and C. Jaramillo, 2010, Clockwise rotation of the Santa Marta massif and simultaneous Paleogene to Neogene deformation of the Plato-San Jorge and Cesar-Ranchería basins: Journal of South American Earth Sciences, 29, 832-848.

Montes, C., A. F. Rodriguez-Corcho, G. Bayona, N. Hoyos, S. Zapata, and A. Cardona, 2019, Continental margin response to multiple arc-continent collisions: The northern AndesCaribbean margin: Earth-Science Reviews, 198.

Montes, C., G. Bayona, A. Cardona, D. M. Buchs, C. A. Silva, S. Morón, N. Hoyos, D. A. Ramírez, C. A. Jaramillo, and V. Valencia, 2012a, Arc-continent collision and orocline formation: Closing of the Central American seaway: Journal of Geophysical Research: Solid Earth, 117, 1-25.

Montes, C., A. Cardona, C. Jaramillo, A. Pardo, J. C. Silva, V. Valencia, C. Ayala, L. C. PerezAngel, L. A. Rodriguez-Parra, V. Ramirez, and H. Nino, 2015, Middle Miocene closure of the Central American Seaway: Science, 348, 226-229.

Montes, C., A. Cardona, R. McFadden, S. E. E. Morón, C. A. A. Silva, S. Restrepo-Moreno, D. A. A. Ramírez, N. Hoyos, J. Wilson, D. Farris, G. Bayona, C. A. A. Jaramillo, V. Valencia, J. Bryan, and J. A. a. Flores, 2012b, Evidence for middle Eocene and younger land emergence in central Panama: Implications for Isthmus closure: Bulletin of the Geological Society of America, 124, 780-799.

Mora-Páez, H., J. N. Kellogg, J. T. Freymueller, D. Mencin, R. M. S. Fernandes, H. Diederix, P. LaFemina, L. Cardona-Piedrahita, S. Lizarazo, J.-R. Peláez-Gaviria, F. Díaz-Mila, O. Bohórquez-Orozco, L. Giraldo-Londoño, and Y. Corchuelo-Cuervo, 2019, Crustal 
deformation in the northern Andes - A new GPS velocity field: Journal of South American Earth Sciences, 89, 76-91.

Müller, R. D., J. Y. Royer, S. C. Cande, W. R. Roest, and S. Maschenkov, 1999, New Constraints on the Late Cretaceous / Tertiary Plate Tectonic Evolution of the Caribbean, in P. Mann, ed., Caribbean Basins. Sedimentary Basins of the World, 4, Vol. 4. Elsevier B.V., $33-59$.

Nicholson, C., L. Seeber, P. Williams, and L. R. Sykes, 1986a, Seismicity and fault kinematics through the Eastern Transverse Ranges, California: Block rotation, strike-slip faulting and low-angle thrusts: Journal of Geophysical Research, 91, 4891.

Nicholson, C., L. Seeber, P. Williams, and L. R. Sykes, 1986b, Seismic evidence for conjugate slip and block rotation within the San Andreas Fault System, Southern California.: Tectonics, 5, 629-648.

Partyka, G., J. Gridley, and J. Lopez, 1999, Interpretational applications of spectral decomposition in reservoir characterization: The Leading Edge, 18.

Peacock, D. C. P., M. W. Anderson, A. Morris, and D. E. Randall, 1998, Evidence for the importance of "small" faults on block rotation: Tectonophysics, 299, 1-13.

Pindell, J. L., and L. Kennan, 2009, Tectonic evolution of the Gulf of Mexico, Caribbean and northern South America in the mantle reference frame: an update: Geological Society, London, Special Publications, 328, 1-55.

Platt, J. P., 2000, Calibrating the bulk rheology of active obliquely convergent thrust belts and forearc wedges from surface profiles and velocity distributions: Tectonics, 19, 529-548.

Ramsay, J. G., and M. I. Huber, 1983, The Techniques of Modern Structural Geology. Volume 1: Strain Analysis: Academic Press.

Richard, P. D., M. A. Naylor, and A. Koopman, 1995, Experimental models of strike-slip tectonics: Petroleum Geoscience, 1, 71-80.

Ron, H., R. Freund, and Z. Garfunkel, 1984, Block rotation by strike-slip faulting: structural and paleomagnetic evidence.: Journal of Geophysical Research, 89, 6256-6270.

Sanderson, D. J., and W. R. D. Marchini, 1984, Transpression: Journal of Structural Geology, 6, 449-458.

Schreurs, G., 1994, Experiments on strike-slip faulting and block rotation: Geology, 22, 567570.

Schreurs, G., 2003, Fault development and interaction in distributed strike-slip shear zones: an experimental approach: Geological Society, London, Special Publications, 210, 35-52.

Symithe, S., E. Calais, J. B. de Chabalier, R. Robertson, and M. Higgins, 2015, Current block motions and strain accumulation on active faults in the Caribbean: Journal of Geophysical Research: Solid Earth, 120, 3748-3774.

Teyssier, C., B. Tikoff, and M. Markley, 1995, Oblique plate motion and continental tectonics: Geology, 23, 447.

Trenkamp, R., J. N. Kellogg, J. T. Freymueller, and H. P. Mora, 2002, Wide plate margin deformation, southern Central America and northwestern South America, CASA GPS observations: Journal of South American Earth Sciences, 15, 157-171.

Vence, E., and P. Mann, 2020, Subsurface basement, structure, stratigraphy, and timing of regional tectonic events affecting the Guajira Margin of Northern Colombia: Interpretation, 8.

Waldron, J. W. F., 2005, Extensional fault arrays in strike-slip and transtension: Journal of Structural Geology, 27, 23-34. 
Wallace, L. M., S. Ellis, and P. Mann, 2009, Collisional model for rapid fore-arc block rotations, arc curvature, and episodic back-arc rifting in subduction settings: Geochemistry, Geophysics, Geosystems, 10, n/a-n/a.

Wallace, L. M., J. Beavan, R. McCaffrey, K. Berryman, and P. Denys, 2007, Balancing the plate motion budget in the South Island, New Zealand using GPS, geological and seismological datas: Geophysical Journal International, 168, 332-352.

Weber, J. C., T. H. Dixon, C. DeMets, W. B. Ambeh, P. Jansma, G. Mattioli, J. Saleh, G. Sella, R. Bilham, and O. Pérez, 2001, GPS estimate of relative motion between the Caribbean and South American plates, and geologic implications for Trinidad and Venezuela: Geology, 29, 75-78.

Yu, G., S. G. Wesnousky, and G. Ekstrom, 1993, Slip Partitioning along Major Convergent Plate Boundaries: Pure and Applied Geophysics, 140, 183-210. 


\section{FIGURE CAPTIONS}

Figure 1. Mechanism to generate sigmoidal-Z normal faults within a dextral shear zone. A) Structures formed in a simple-dextral shear zone; faults and folds form at $45^{\circ}$ to the boundaries of the zone. Note the change in the strike of the structures in transpressional or transtensional settings. B) Incremental strain at $\Psi=30^{\circ}$. C) Incremental strain at $\Psi=45^{\circ}$. D) Incremental strain at $\Psi=60^{\circ}$. E) Sigmoidal normal faults as a result of the incremental strain within a simple-dextral shear zone.

Figure 2. A) Location of the study area in the NW corner of South America. The Bahia Basin is in front of the NW corner of the Santa Marta Massif, at the end of two regional strike-slip fault systems: the EW trending Oca Fault System (OFS), and the NW-SE trending Santa Marta-Bucaramanga Fault (SMBFS). Faults A, B, C and D are the main faults observed in the Bahia Basin. B) NW-SE cross section showing the South Caribbean Deformed Belt and the Bahia Basin towards the rear of the accretionary prism (modified from Galindo and Lonergan, 2020).

Figure 3. A) Upper Miocene to lower Pliocene unconformity time-structure map. The NESW trending Bahia Fault compartmentalizes de basin and separates the high blocks in the NW ( $\mathrm{SH}=$ Southern High, $\mathrm{CH}=$ Central High, $\mathrm{NH}=$ Northern High) from the main depocenter in the SE. The blue box highlights the location of the focus area in the northern high. The contour interval is $100 \mathrm{~ms}$ TWT. B) Upper Miocene to lower Pliocene unconformity structure map. Faults A, C and D form the boundaries to the Bahia Basin. Bahia Fault is formed by three main segments $(\mathrm{Bs}=\mathrm{Bahia}$ south, $\mathrm{Bc}=\mathrm{Bahia}$ central, $\mathrm{Bn}=\mathrm{Bahia}$ north $)$. Note 
the North position towards the upper right corner (modified from Galindo and Lonergan, 2020)

Figure 4. Uninterpreted (above) and interpreted (below) S-N seismic section across the northern high of the Bahia basin showing the closely spaced, low-displacement, extensional faults. Colored horizons correspond to main unconformities interpreted within the basin: in green, UMLPU (Upper Miocene to Lower Pliocene Unconformity); in blue, MMU (Middle Miocene Unconformity); in magenta, UOLMU (Upper Miocene to Lower Miocene Unconformity); in orange, MEU (Middle Eocene Unconformity).

Figure 5. Seismic data used for the interpretation of faults below the upper Miocene to lower Pliocene unconformity in the area of the northern high. A) Time slice at $3160 \mathrm{~ms}$. B) Coherency at Time slice at $3160 \mathrm{~ms}$. C) Spectral decomposition 0-250 ms below UMLPU at $13 \mathrm{~Hz}$. D) Interpretation of faults below the upper Miocene to lower Pliocene unconformity. For location of time slice and attributes, see Figure 4.

Figure 6. Schematic map showing the oblique subduction of the Caribbean Plate and the occurrence of a dextral strike-slip deformation zone at the rear of the South Caribbean Deformed Belt. Note the formation of sigmoidal faults within the dextral shear zone, and the corresponding clockwise vertical-axis block rotation (modified from Galindo and Lonergan, 2013) 


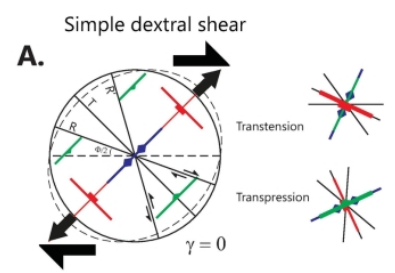

D.

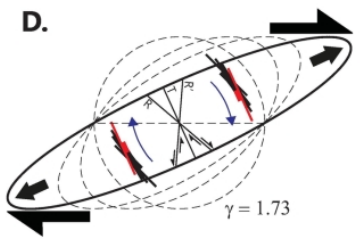

B.

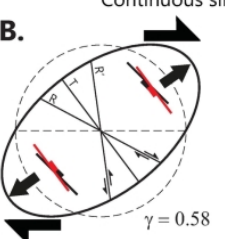

E.

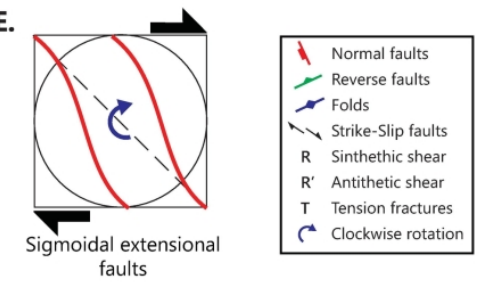

Figure 1. Mechanism to generate sigmoidal-Z normal faults within a dextral shear zone. A) Structures formed in a simple-dextral shear zone; faults and folds form at $45^{\circ}$ to the boundaries of the zone. Note the change in the strike of the structures in transpressional or transtensional settings. B) Incremental strain at $\Psi=30^{\circ}$. C) Incremental strain at $\Psi=45^{\circ}$. D) Incremental strain at $\Psi=60^{\circ}$. E) Sigmoidal normal faults as a result of the incremental strain within a simple-dextral shear zone.

$224 \times 95 \mathrm{~mm}(300 \times 300$ DPI $)$ 
Figure 2. A) Location of the study area in the NW corner of South America. The Bahia Basin is in front of the NW corner of the Santa Marta Massif, at the end of two regional strike-slip fault systems: the EW trending Oca Fault System (OFS), and the NW-SE trending Santa Marta-Bucaramanga Fault (SMBFS). Faults A, B, C and $\mathrm{D}$ are the main faults observed in the Bahia Basin.

$184 \times 127 \mathrm{~mm}(300 \times 300 \mathrm{DPI})$ 


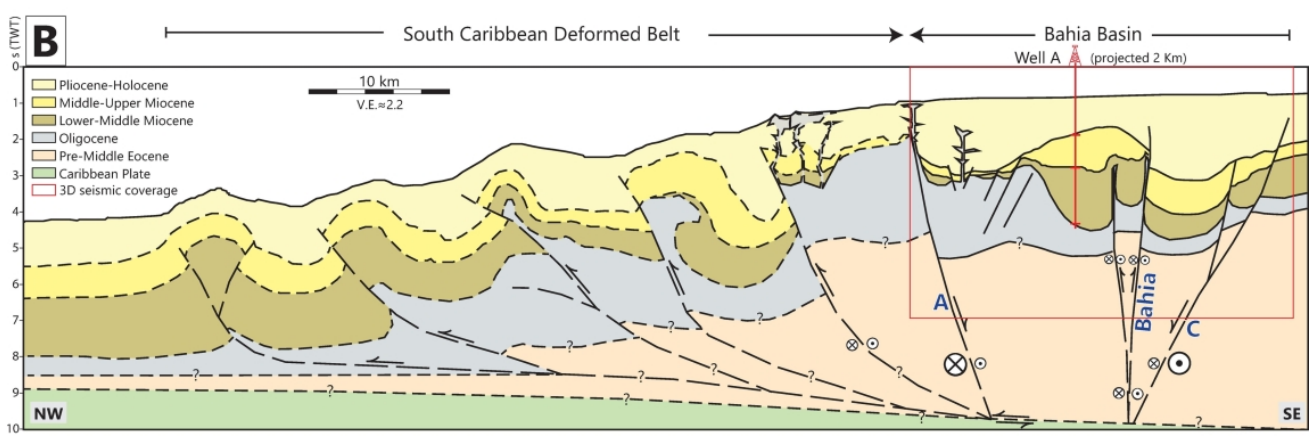

B) NW-SE cross section showing the South Caribbean Deformed Belt and the Bahia Basin towards the rear of the accretionary prism (modified from Galindo and Lonergan, 2020).

$279 \times 170 \mathrm{~mm}(300 \times 300 \mathrm{DPI})$ 

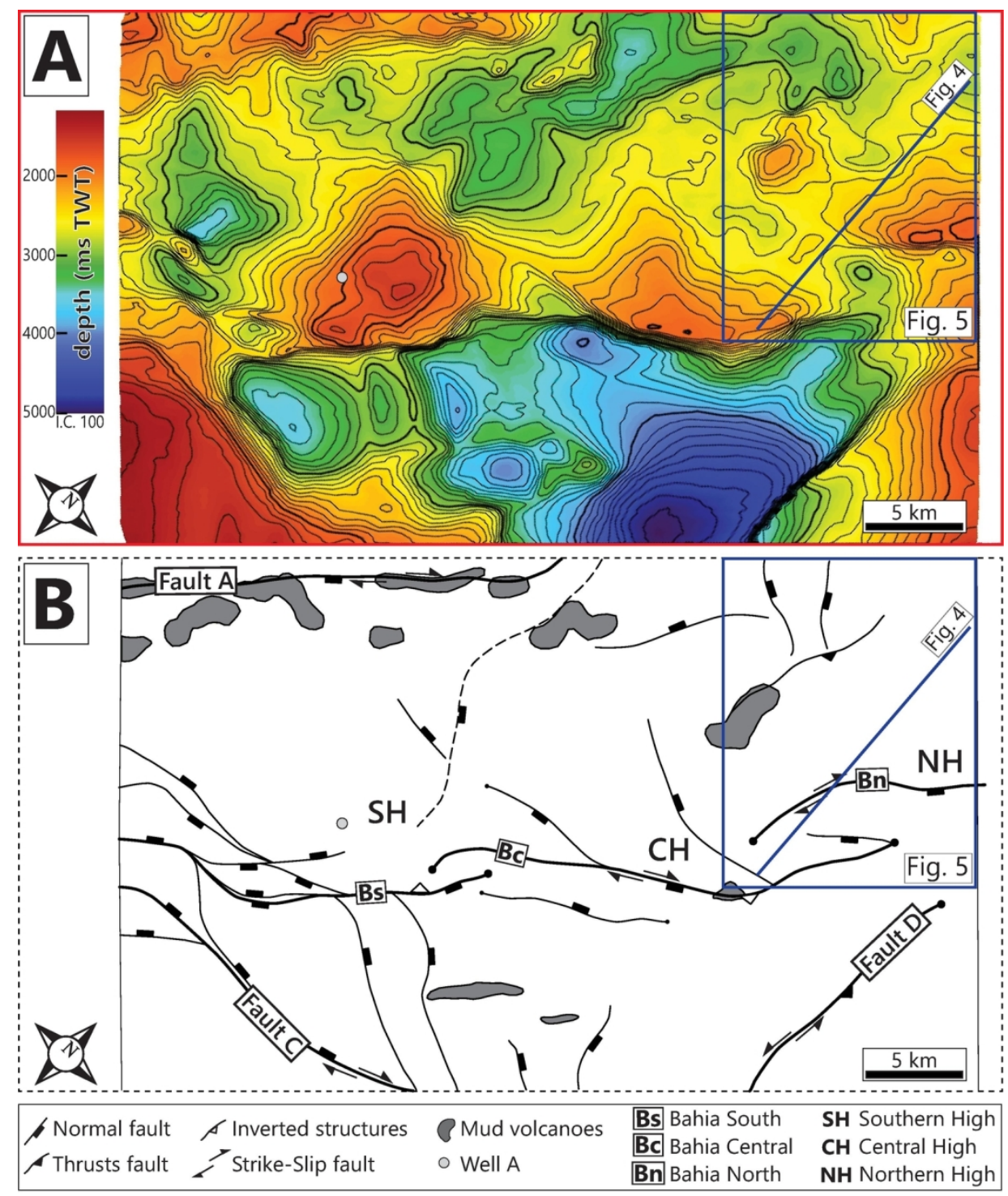

Figure 3. A) Upper Miocene to lower Pliocene unconformity time-structure map. The NE-SW trending Bahia Fault compartmentalizes de basin and separates the high blocks in the NW ( $\mathrm{SH}=$ Southern High, $\mathrm{CH}=$ Central High, $\mathrm{NH}=$ Northern High) from the main depocenter in the SE. The blue box highlights the location of the focus area in the northern high. The contour interval is $100 \mathrm{~ms}$ TWT. B) Upper Miocene to lower Pliocene unconformity structure map. Faults $A, C$ and $D$ form the boundaries to the Bahia Basin. Bahia Fault is formed by three main segments ( $B s=B a h i a$ south, $B c=B a h i a$ central, $B n=B a h i a$ north). Note the North position towards the upper right corner (modified from Galindo and Lonergan, 2020)

\section{$130 \times 167 \mathrm{~mm}(300 \times 300 \mathrm{DPI})$}



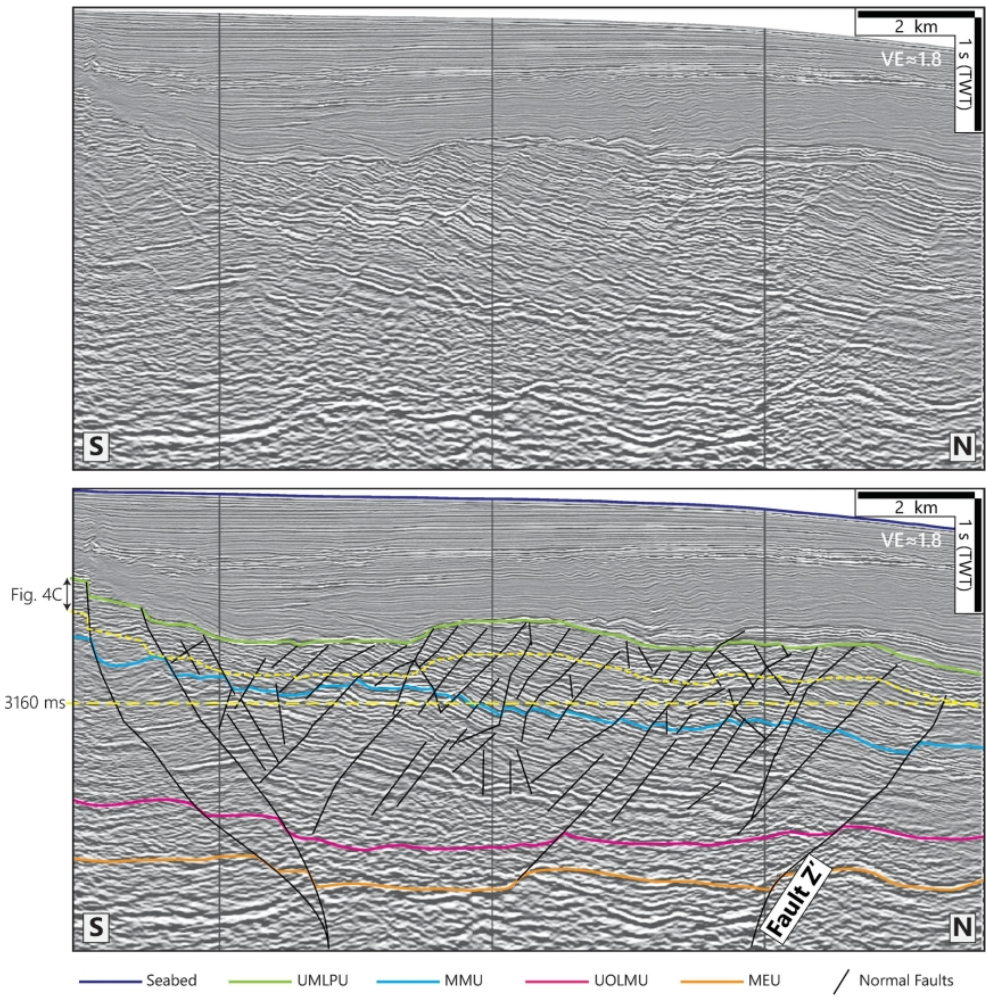

Figure 4. Uninterpreted (above) and interpreted (below) S-N seismic section across the northern high of the Bahia basin showing the closely spaced, low-displacement, extensional faults. Colored horizons correspond to main unconformities interpreted within the basin: in green, UMLPU (Upper Miocene to Lower Pliocene Unconformity); in blue, MMU (Middle Miocene Unconformity); in magenta, UOLMU (Upper Miocene to Lower Miocene Unconformity); in orange, MEU (Middle Eocene Unconformity).

$207 \times 181 \mathrm{~mm}(300 \times 300$ DPI $)$ 

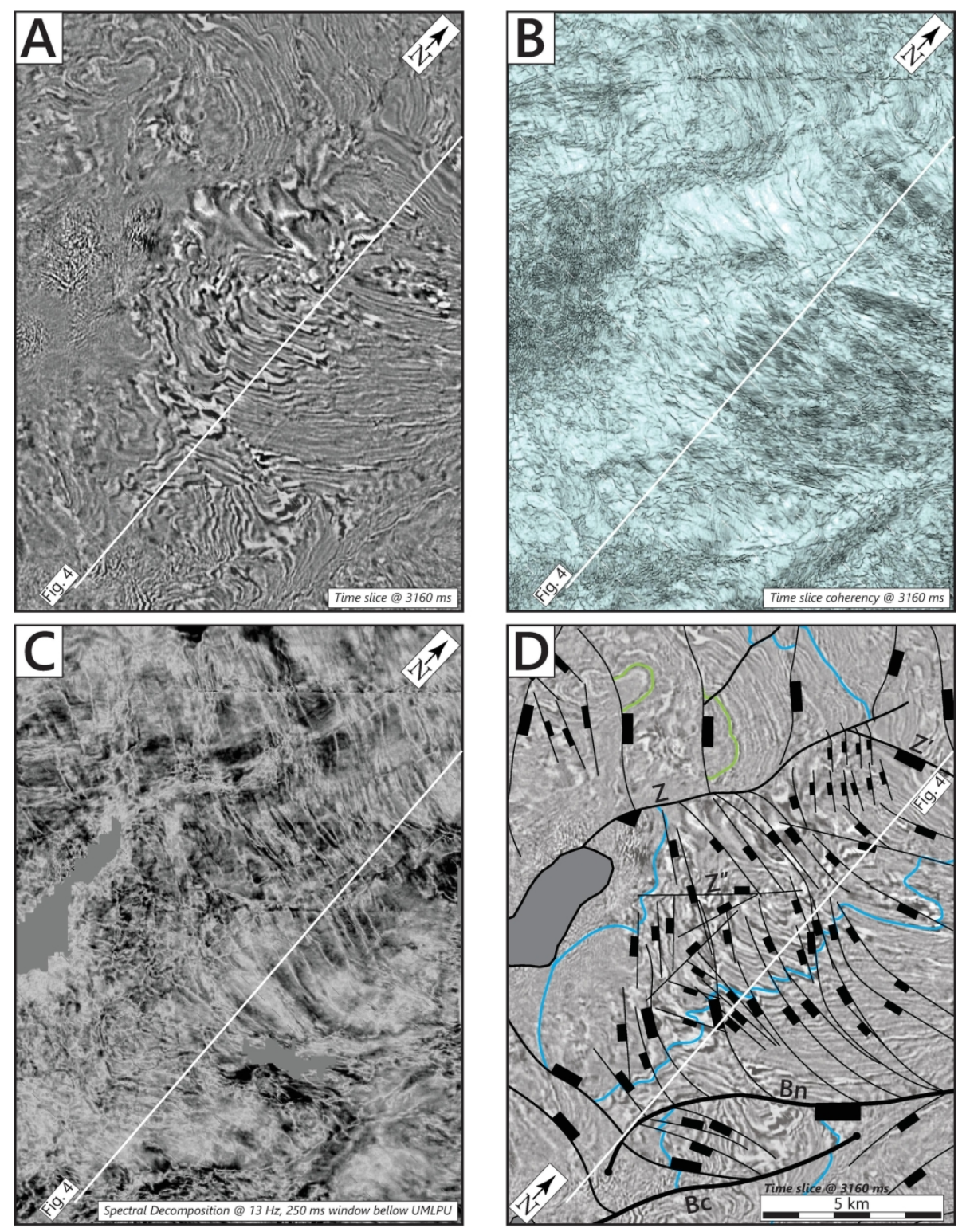

Figure 5. Seismic data used for the interpretation of faults below the upper Miocene to lower Pliocene unconformity in the area of the northern high. A) Time slice at $3160 \mathrm{~ms}$. B) Coherency at Time slice at 3160 ms. C) Spectral decomposition 0-250 ms below UMLPU at $13 \mathrm{~Hz}$. D) Interpretation of faults below the upper Miocene to lower Pliocene unconformity. For location of time slice and attributes, see Figure 4.

$160 \times 212 \mathrm{~mm}(300 \times 300 \mathrm{DPI})$ 


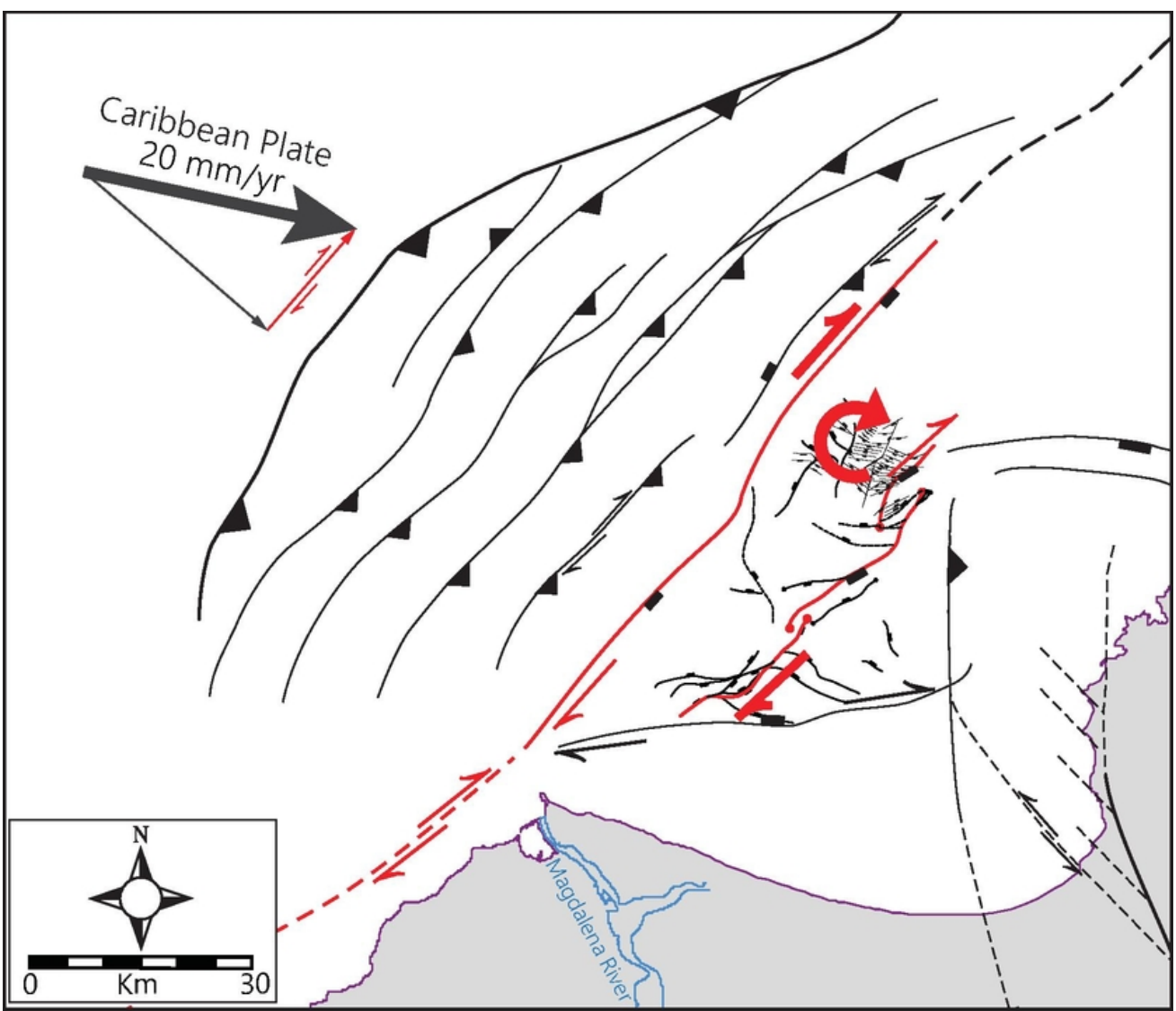

Figure 6. Schematic map showing the oblique subduction of the Caribbean Plate and the occurrence of a dextral strike-slip deformation zone at the rear of the South Caribbean Deformed Belt. Note the formation of sigmoidal faults within the dextral shear zone, and the corresponding clockwise vertical-axis block rotation (modified from Galindo and Lonergan, 2013)

$70 \times 60 \mathrm{~mm}(300 \times 300$ DPI $)$ 